Laporan Penelitian

\title{
Hubungan status nutrisi penderita karsinoma nasofaring stadium lanjut dengan kejadian mukositis sesudah radioterapi
}

\author{
Fransiska Tricia, Pudji Rahaju, Rus Suheryanto \\ Laboratorium Ilmu Kesehatan Telinga Hidung Tenggorok Kepala Leher \\ Fakultas Kedokteran Universitas Brawijaya/ \\ Rumah Sakit Umum Dr. Saiful Anwar \\ Malang
}

\begin{abstract}
ABSTRAK
Latar belakang: Status nutrisi normal menggambarkan keseimbangan yang baik antara asupan nutrisi dengan kebutuhan nutrisi. Kekurangan nutrisi pada penderita kanker memberikan efek yang tidak diinginkan terhadap struktur dan fungsi hampir semua organ dan sistem tubuh. Tujuan: Penelitian ini untuk mengetahui perbedaan status nutrisi penderita karsioma nasofaring (KNF) WHO tipe III stadium lanjut sebelum dan sesudah radioterapi, hubungan status nutrisinya dengan kejadian mukositis sesudah radioterapi. Metode: Penelitian ini adalah observasional analitik, dengan jumlah sampel 10 penderita KNF. Analisis statistik menggunakan paired sample t test dan uji korelasi Spearman. Hasil: Terdapat perbedaan yang bermakna antara status nutrisi dengan parameter Body Mass Index (BMI), lingkar otot lengan atas (LOLA) dan transferin sebelum dan sesudah radioterapi (BMI $p=0,000$, LOLA $p=0,001$ dan transferin $\mathrm{p}=0,005$ dengan $\mathrm{p}<0,05$ ). Pada paired sample t test albumin sebelum dan sesudah radioterapi menunjukkan nilai $\mathrm{p}=0,205$ yang berarti bahwa radioterapi tidak menyebabkan penurunan albumin yang bermakna. Uji korelasi hubungan antara BMI, LOLA, albumin, dan transferin sebelum radioterapi dengan kejadian mukositis menunjukkan bahwa status nutrisi tidak berhubungan dengan kejadian mukositis (BMI $\mathrm{p}=0,062$, LOLA $\mathrm{p}=0,209$, albumin $\mathrm{p}=0,904$, transferin $\mathrm{p}=0,631$ dengan $\mathrm{p}>0,05$ ). Uji korelasi hubungan antara BMI, LOLA, albumin, dan transferin sesudah radioterapi menunjukkan bahwa status nutrisi tidak berhubungan secara signifikan dengan kejadian mukositis sesudah radioterapi (BMI $p=0,122$, LOLA $\mathrm{p}=0,209$, albumin $\mathrm{p}=0,902$ dan transferin $\mathrm{p}=1,000$ dengan $\mathrm{p}>0,05)$ Kesimpulan: Pemberian radioterapi pada penderita KNF stadium lanjut menyebabkan penurunan bermakna pada status nutrisi sebelum dan sesudah radioterapi, tetapi tidak berhubungan secara bermakna dengan kejadian mukositis sesudah radioterapi.
\end{abstract}

Kata kunci: karsinoma nasofaring, radioterapi, status nutrisi, malnutrisi, mukositis.

\section{ABSTRACT}

Background: Normal nutritional status is a balanced condition of nutritional intake and requirement in a person. Lack of nutrition in cancer patients promotes undesirable effects on various organs and systems of the body. Purpose: To determine the nutritional status differences in patients with advanced stage NPC type III WHO before and after radiotherapy, and the relationship between nutritional status with mucositis occurance after radiotherapy. Method: Observational analytic study. Sampling was conducted by non-random purposive sampling technique with 10 subjects with NPC. The statistical analysis used paired sample Wilcoxon test and Spearman correlation test. Result: The study found significant differences between nutritional state regarding BMI, LOLA and transferrin before and after radiotherapy with $p<0.05$. Paired sample t test of BMI, LOLA, transferrin before and after radiotherapy demonstrated $B M I p=0.000, L O L A p=0.001$ and transferrin $p=0.005$. The paired sample $t$ test for albumin before and 
after radiotherapy showed that radiotherapy did not cause significant decrease in albumin. Correlation test to determine the relationship among BMI, LOLA, albumin, and transferrin before radiotherapy with mucositis occurance showed BMI $p=0.062$, LOLA $p=0.209, p=0.904$ albumin, transferrin $p=0.631$ which meant that nutritional state has no corelation with mucositis occurance. While after radiotherapy it showed $B M I p=0.122, p=0.209$ LOLA, albumin, $p=0.902$ and transferrin $p=1.000$ which meant that nutritional state after radiotherapy has no corelation to the occurance of mucositis. Conclusion: Radiotherapy in patients with advanced-stage of NPC caused a significant difference in nutritional state before and after radiotherapy, but had no significant association with mucositis occurance.

Keywords: nasopharyngeal carcinoma, radiotherapy, nutritional state, malnutrition, mucositis.

Alamat korespondensi: Fransiska Tricia, Lab/SMF Ilmu Kesehatan THT-KL FK Unibraw/RSUD Dr. Saiful Anwar Malang. E-mail: dalopeztricia@yahoo.com.

\section{PENDAHULUAN}

Karsinoma nasofaring (KNF) merupakan tumor ganas kepala dan leher yang sering ditemukan di Asia dan Cina bagian selatan, namun jarang dijumpai di

Eropa dan Amerika. KNF termasuk dalam sepuluh besar keganasan yang ada di Asia Tenggara terutama di Cina Selatan, Hongkong, Singapura, dan Taiwan dengan insidens 10-53 kasus tiap 100.000 penduduk pertahun. Insidens KNF di negara-negara barat sebesar 1 kasus tiap 100.000 penduduk pertahun. Insidens KNF di Indonesia pernah dilaporkan sebesar 4,7 per 100.000 penduduk pertahun. Data pencatatan medik RSUD Dr. Saiful Anwar Malang didapatkan kasus baru KNF sebesar 45 penderita selama tahun 2007, 46 penderita selama tahun 2008, 37 penderita pada tahun 2009 dan 40 penderita pada tahun 2010. Angka kejadian keganasan nasofaring pada dewasa lebih dari $95 \%$ dan pada anak 20\%-30\%. ${ }^{1-4}$

Diagnosis klinis KNF seringkali sulit karena letak nasofaring yang tersembunyi, sehingga sebagian besar penyakit sudah berkembang menjadi stadium lanjut pada saat pertama kali didiagnosis. Sangat mencolok perbedaan angka ketahanan hidup 5 tahun antara stadium awal dibandingkan dengan stadium lanjut, yaitu $76,9 \%$ untuk stadium I, 56,0\% untuk stadium II, 38,4\% untuk stadium III, dan hanya 16,4 \% untuk stadium IV.
Keadaan malnutrisi sering dijumpai pada pasien kanker yang dikenal dengan istilah kakhesia kanker. Keadaan ini mempunyai dampak pada morbiditas, mortalitas dan kualitas hidup penderita keganasan. Definisi kakhesia kanker merupakan sindroma multi organ ditandai dengan penurunan berat badan (minimal 5\%), hilangnya massa otot, lemak dan adanya inflamasi. Keadaan ini biasanya berhubungan dengan anoreksia, dan gangguan dalam metabolisme karbohidrat, lemak dan protein. Penderita keganasan kepala dan leher dapat mengalami penurunan berat badan sebesar $10 \%$ dari berat badan sebelum terapi, selama menjalani radioterapi dan terapi kombinasi. Penurunan berat badan lebih dari $20 \%$ akan meningkatkan toksisitas dan mortalitas selama terapi. Selain itu penurunan berat badan akan meningkatkan komplikasi seperti gangguan penyembuhan luka, penurunan fungsi sistem imun dan penurunan toleransi terhadap kemoterapi dan radioterapi. Keadaan ini akan berdampak pada lamanya waktu perawatan dan menyebabkan hasil terapi yang jelek..$^{6,7}$

Terapi radiasi pasien KNF di Instalasi Rawat Jalan THT RSUD Dr. Saiful Anwar Malang saat ini bekerja sama dengan Instalasi Radioterapi dilakukan dengan menggunakan radiasi ionisasi yang menyebabkan kematian sel dengan cara pembentukan radikal bebas melalui dua mekanisme. Mekanisme pertama yakni apoptosis yang menyebabkan kematian sel 
dalam beberapa jam sesudah radiasi. Mekanisme kedua adalah dengan menginduksi kegagalan mitosis dan menghambat proliferasi selular, yang kemudian dapat mematikan sel-sel kanker. Pada perkembangan saat ini, target utama radioterapi adalah melalui kerusakan deoxyribonucleid acid (DNA) seluler. ${ }^{8}$

Efek samping dari terapi kanker adalah mukositis oral, terutama disebabkan terapi radiasi pada kanker daerah kepala dan leher dan berbagai jenis kemoterapi. Mukositis oral menyebabkan nyeri, kesulitan makan, menelan dan bicara yang dapat menyebabkan infeksi sekunder, penurunan berat badan dan dapat menyebabkan penderita tidak bisa melanjutkan terapi. ${ }^{9}$

Beberapa penelitian melaporkan bahwa kurang lebih $40-80 \%$ pasien mengalami malnutrisi, dan diperkirakan sekitar 20\% pasien kanker meninggal tiap tahunnya akibat malnutrisi. Malnutrisi dan kakhesia sering terjadi pada penderita kanker $24 \%$ pada stadium dini dan $>80 \%$ pada stadium lanjut. Pada keganasan kepala dan leher, lebih dari 40\% penderita mengalami malnutrisi saat ditegakkan diagnosis keganasan. Pada penelitian yang lain insiden penurunan berat badan berdasarkan asal tumor sebesar $83 \%$ pada kanker pankreas dan lambung, $79 \%$ pada esofagus, dan $72 \%$ pada kanker kepala dan leher. Terapi kanker juga berpengaruh terhadap status nutrisi penderita. Pada suatu penelitian didapatkan $>40 \%$ penderita yang mendapat terapi kanker (bedah, kemoterapi dan radiasi) mengalami malnutrisi. ${ }^{10-13}$

Penelitian ini bertujuan mengetahui perbedaan status nutrisi penderita KNF WHO tipe III stadium lanjut sebelum dan sesudah radioterapi, serta hubungan status nutrisi sebelum dan sesudah radioterapi dengan kejadian mukositis sesudah radioterapi.

\section{METODE}

Desain penelitian yang digunakan adalah observasional analitik. Penderita KNF yang akan dilakukan radioterapi dinilai status nutrisinya dengan parameter Body Mass Index (BMI), lingkar otot lengan atas (LOLA), albumin dan transferrin. Selanjutnya dilakukan radioterapi sebanyak 35 kali dengan dosis total 7000 cGy dengan fraksinasi pemberian $200 \mathrm{cGy}$ dan waktu pemberian 5 kali seminggu. Pada pertengahan radioterapi hari ke-20 akan dilakukan pemeriksaan BMI, LOLA dan derajat mukositis. Sesudah radioterapi diselesaikan dilakukan penilaian kembali status nutrisi (BMI, LOLA, albumin, transferin) serta dinilai mukositis sebagai efek samping radioterapi.

Penelitian dilakukan di RSUD Dr. Saiful Anwar Malang dan dilaksanakan mulai bulan Mei 2011 sampai dengan Oktober 2011. Populasi adalah penderita KNF yang datang berobat ke RSUD Dr. Saiful Anwar Malang. Sampel adalah populasi yang memenuhi kriteria inklusi yaitu penderita KNF baru stadium lanjut (III dan IV) menurut UICC 2002 dengan histopatologi karsinoma undifferentiated (WHO tipe III), memenuhi persyaratan untuk mendapatkan radioterapi, $\mathrm{Hb}$ tidak boleh kurang dari $10 \mathrm{~g} \%$, jumlah lekosit tidak boleh kurang dari 3000 per $\mathrm{mm}^{3}$, trombosit minimum 100.000 per $\mu \mathrm{L}$ dan bersedia diikutkan dalam penelitian.

Variabel pada penelitian ini meliputi variabel bebas yaitu pemberian radioterapi dan variabel tergantung yang terdiri BMI, LOLA, albumin, transferin dan derajat mukositis berdasarkan WHO, yaitu $0=$ Tidak ada mukositis, $1=$ Timbul nyeri dan eritema, 2 = Eritema dan ulkus, pasien masih bisa menelan makanan padat, $3=$ Eritema yang luas dan terbentuk ulkus pasien tidak bias menelan makanan padat, $4=$ Mukositis yang luas dan makanan tidak bisa masuk.

Perbedaan status nutrisi sebelum dan sesudah radioterapi dapat diuji dengan paired sample $t$ test, untuk mengetahui hubungan antara status nutrisi sebelum radioterapi dengan kejadian mukositis sesudah radioterapi dilakukan dengan uji korelasi Spearman dan hubungan antara status nutrisi sesudah radioterapi dengan kejadian mukositis sesudah radioterapi dilakukan dengan uji korelasi Spearman. 


\section{HASIL}

Karakteristik subyek yang didata dalam penelitian ini meliputi jenis kelamin, usia, stadium dan efek samping radioterapi. Dari 10 penderita yang diteliti selama radioterapi, sebagian besar adalah laki-laki (70\%), berusia lebih dari 40 tahun (60\%) dan telah memasuki stadium lanjut IV B (60\%) stadium IV A (30\%) dan stadium III (10\%). Efek samping yang muncul adalah serostomia (80\%), gangguan pengecapan (100\%), hiperpigmentasi kulit $(100 \%)$ dan mukositis (80\%).
Tabel 1 di atas menunjukkan bahwa pasien pada saat sebelum radioterapi dan sesudah radioterapi mempunyai rata-rata $\mathrm{BMI}$ sebelum radioterapi sebesar 20.83 yang lebih besar daripada BMI sesudah radioterapi sebesar 18.48. Nilai rata-rata LOLA sebelum radioterapi sebesar 21.39, lebih besar daripada nilai rata-rata LOLA sesudah radioterapi sebesar 19.29. Nilai ratarata albumin sebelum radioterapi sebesar 3.97, lebih besar daripada albumin sesudah radioterapi sebesar 3.81. Demikian juga nilai rata-rata transferin sebelum radioterapi sebesar 215.56,

Tabel 1. Hasil paired sampel t test status nutrisi penderita KNF sebelum dan sesudah radioterapi

\begin{tabular}{|c|c|c|c|c|c|}
\hline \multirow{2}{*}{ Status Nutrisi } & \multicolumn{2}{|c|}{ Sebelum Radioterapi } & \multicolumn{2}{|c|}{ Sesudah Radioterapi } & \multirow{2}{*}{$\begin{array}{l}\text { Nilai } p \text { dari paired } \\
\text { sample t test }\end{array}$} \\
\hline & Mean & $\pm \mathrm{SD}$ & Mean & \pm SD & \\
\hline BMI & 20,83 & 3,30 & 18,48 & 2,95 & 0,000 \\
\hline LOLA & 21,39 & 2,42 & 19,29 & 2,16 & 0,001 \\
\hline Albumin & 3,97 & 0,26 & 3,81 & 0,48 & 0,207 \\
\hline Transferin & 215,56 & 46,59 & 187,11 & 49,03 & 0,005 \\
\hline
\end{tabular}
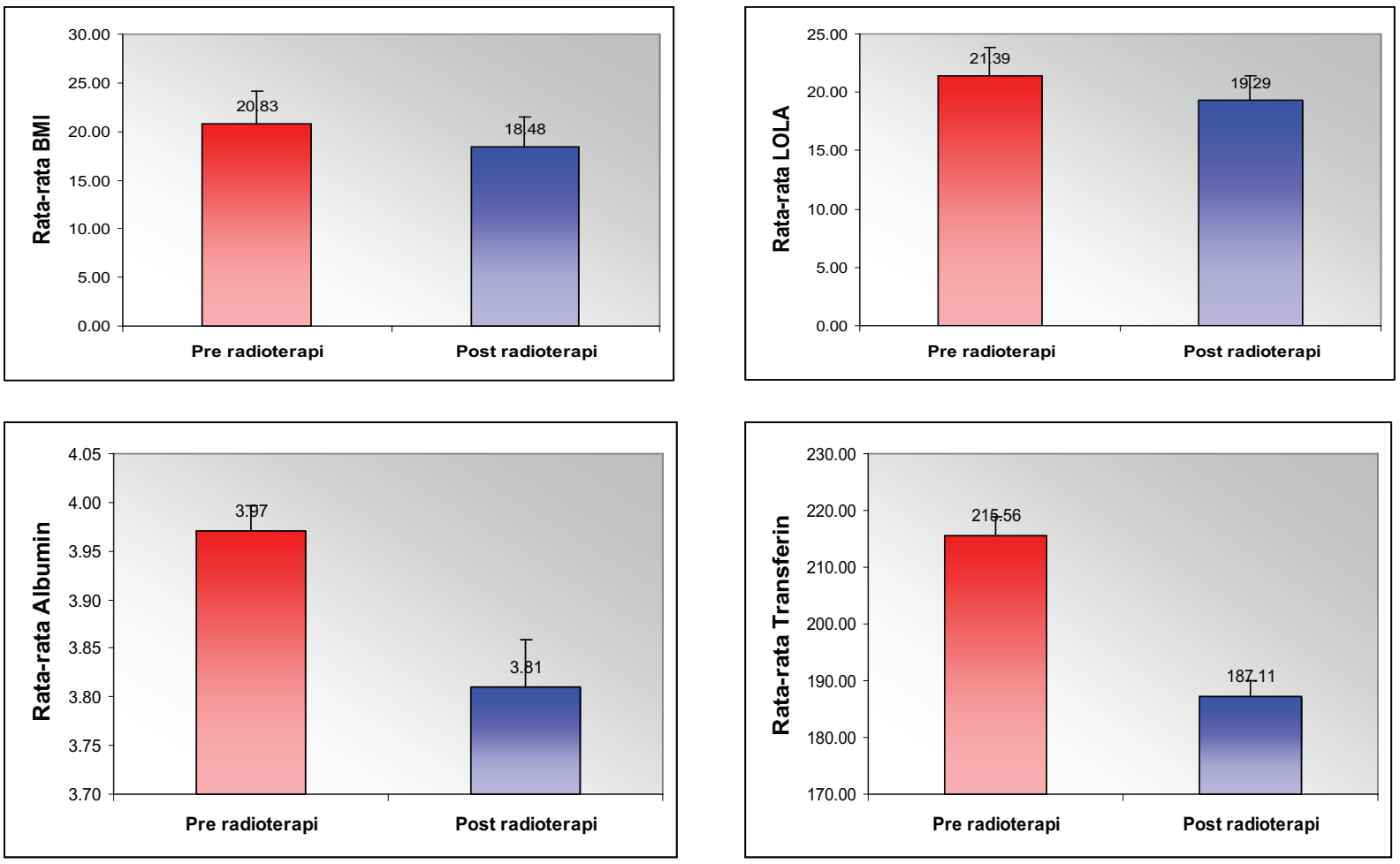

Gambar 1. Grafik rata-rata dan simpangan baku pada BMI, LOLA, albumin dan transferin pada saat sebelum radioterapi dan sesudah radioterapi. 
lebih besar daripada transferin sesudah radioterapi sebesar 187.11.

Berdasarkan hasil paired sampel t test untuk BMI, LOLA, dan transferin menunjukkan nilai signifikansi masing-masing sebesar 0.000, 0.001 dan $0.005(\mathrm{p}<0.05)$, sehingga dapat diartikan bahwa BMI, LOLA, dan transferin antara sebelum radioterapi dan sesudah radioterapi menunjukkan adanya perbedaan yang signifikan. Sedangkan untuk albumin pasien menunjukkan nilai signifikansi sebesar 0.205 ( $p>0.05)$, sehingga dapat diartikan bahwa albumin pasien antara sebelum radioterapi dan sesudah radioterapi tidak menunjukkan adanya perbedaan yang signifikan.

Pada saat pertengahan radioterapi hari ke-20 sebanyak $70 \%$ pasien tidak mengalami mukositis atau derajat 0 , tetapi sesudah menjalani radioterapi ada $80 \%$ pasien yang mengalami mukositis derajat 1. Berdasarkan hasil uji Wilcoxon menunjukkan nilai signifikansi sebesar 0.025 $(p<0.05)$, sehingga dapat diartikan bahwa terdapat perbedaan yang bermakna terjadinya mukositis pertengahan radioterapi hari ke-20 dan sesudah radioterapi, seperti yang ditunjukkan pada tabel 2 .

Tabel 2. Hasil uji Wilcoxon mukositis pertengahan radioterapi hari ke-20 dengan sesudah radioterapi.

\begin{tabular}{cccccc}
\hline $\begin{array}{c}\text { Derajat } \\
\text { mukositis }\end{array}$ & \multicolumn{2}{c}{$\begin{array}{c}\text { Pertengahan } \\
\text { radioterapi } \\
\text { hr ke-20 }\end{array}$} & \multicolumn{2}{c}{$\begin{array}{c}\text { Sesudah } \\
\text { radioterapi }\end{array}$} & $\begin{array}{c}\text { Nilai p } \\
\text { dari uji } \\
\text { Wilcoxon }\end{array}$ \\
\hline $\mathbf{n}$ & $\mathbf{\%}$ & n & \% & \\
\hline $\mathbf{1}$ & 7 & $70 \%$ & 2 & $20 \%$ & \\
\hline
\end{tabular}

Berdasarkan uji korelasi status nutrisi sebelum dan sesudah radioterapi dengan kejadian mukositis menunjukkan bahwa hubungan antara BMI, LOLA, albumin dan transferin pada saat sebelum radioterapi dengan kejadian mukositis menunjukkan nilai signifikansi sebesar 0.062, $0.209,0.904$, dan 0.631 yang lebih besar dari alpha 0.05 ( $>00.05)$, sehingga Ho ditolak dan dapat disimpulkan bahwa hubungan antara BMI, LOLA, albumin dan transferin pada saat sebelum radioterapi dengan terjadinya mukositis adalah tidak signifikan (tabel 3).
Tabel 3. Hasil uji korelasi Spearman status nutrisi sebelum dan sesudah radioterapi dengan kejadian mukositis.

\begin{tabular}{ccc}
\hline Status nutrisi & $\begin{array}{c}\text { Koefisien } \\
\text { korelasi } \\
\text { Spearman (rs) }\end{array}$ & Nilai p \\
\hline $\begin{array}{c}\text { Sebelum } \\
\text { radioterapi: } \\
\text { BMI }\end{array}$ & 0,609 & 0,062 \\
LOLA & 0,435 & 0,209 \\
Albumin & 0,044 & 0,904 \\
Transferin & 0,174 & 0,631 \\
Sesudah & & \\
radioterapi: & 0,522 & 0,122 \\
BMI & 0,435 & 0,209 \\
LOLA & 0.045 & 0,902 \\
Albumin & 0.000 & 1,000 \\
Transferin & & \\
\hline
\end{tabular}

Demikian pula dengan hubungan antara mukositis dengan BMI, LOLA, albumin dan transferin sesudah radioterapi menunjukkan nilai signifikansi sebesar $0.122,0.209,0.902$, dan 1.000 yang lebih besar dari alpha $0.05(\mathrm{p}>0.05)$, sehingga Ho ditolak dan dapat disimpulkan bahwa hubungan kejadian mukositis dengan BMI, LOLA, albumin dan transferin sesudah radioterapi juga tidak signifikan.

Tabel 4. Hasil uji korelasi Spearman usia, jenis kelamin dan stadium dengan kejadian mukositis

\begin{tabular}{cccc}
\hline Variabel & $\begin{array}{c}\text { Koefisien korelasi } \\
\text { Spearman (rs) }\end{array}$ & Nilai p \\
\hline Usia & - & 0,435 & 0,209 \\
Jenis kelamin & - & 0,218 & 0,545 \\
Stadium & - & 0,398 & 0,254 \\
\hline
\end{tabular}

Berdasarkan tabel 4 di bawah, menunjukkan bahwa hubungan antara usia jenis kelamin dan stadium dengan kejadian mukositis menunjukkan nilai signifikansi sebesar $0,209,0,545$ dan 0,254 yang lebih besar dari alpha $0,05(\mathrm{p}>0,05)$, sehingga Ho ditolak dan dapat disimpulkan bahwa hubungan antara usia, jenis kelamin dan stadium dengan terjadinya mukositis adalah tidak signifikan. 


\section{DISKUSI}

Penderita KNF dapat ditemukan pada semua umur, namun insiden tertinggi pada umur 40-60 tahun dengan rasio laki-laki dan wanita sebesar 3:1. Dari 10 penderita yang dijadikan sampel, sebagian besar sudah memasuki stadium IVB (60\%), stadium IVA(10\%) dan stadium III (30\%) yang ketiganya termasuk stadium lanjut. Penderita sebagian besar datang pada stadium lanjut oleh karena tumor primer sulit diketahui secara dini dan KNF dikenal sebagai tumor ganas yang berpotensi tinggi menimbulkan metastasis regional maupun jauh. Sering terjadi kesalahan diagnosis awal karena tidak jelasnya gejala dan sulitnya pemeriksaan pada nasofaring. Sebanyak $80 \%$ penderita yang datang ke RSUD Dr. Soetomo datang pada stadium III dan IV. Berdasarkan stadium, penderita KNF di RSUD Dr. Saiful Anwar stadium I sebanyak 1 kasus $(0,81 \%)$, stadium II sebanyak 6 kasus $(4,88 \%)$, stadium III sebanyak 47 kasus $(38,21 \%)$ dan stadium IV sebanyak 69 kasus $(56,10 \%)$.

Efek samping radioterapi yang terjadi antara lain mukositis (80\%), serostomia (80\%), gangguan pengecapan (100\%), hiperpigmentasi kulit $(100 \%) .{ }^{3,8}$

Mukositis akibat radiasi adalah proses reaktif yang menyerupai peradangan pada membran mukosa orofaring dan terjadi sesudah terapi radiasi pada penderita kanker kepala dan leher. Penderita kanker kepala dan leher yang menerima terapi radiasi 30\%-60\% menderita mukositis. Insiden oral mukositis 85\%-100\% terdapat pada pasien kanker kepala dan leher yang diradiasi. Serostomia sebagai efek samping radioterapi yang lain menyebabkan pasien sering mengeluh mulut kering oleh karena kelenjar parotis yang memproduksi air liur menerima dosis radiasi sebanyak radiasi eksterna yang diterima nasofaring. Gangguan pengecapan merupakan respon awal radioterapi dan biasanya dimulai dengan mukositis. Kerusakan mukosa oral dan taste bud sangat berkaitan erat dengan dosis radiasi, besar fraksi dan luas jaringan serta teknik radiasi. Hiperpigmentasi kulit merupakan efek samping akut lokal pada kulit dalam lintasan radiasi dimulai dengan hiperemi, hiperpigmentasi dan kadang terjadi deskuamasi pada akhir radiasi. ${ }^{9}, 14,15$

BMI banyak digunakan di rumah sakit untuk mengukur status nutrisi pasien karena BMI dapat memperkirakan ukuran lemak tubuh yang sekalipun hanya estimasi tetapi lebih akurat daripada pengukuran berat badan saja. Berat badan tidak memberikan informasi mengenai komposisi tubuh dan tidak efektif untuk menentukan penyakit kronis. Pasien yang berukuran tubuh besar tetapi bukan gemuk dapat memiliki BMI diatas nilai standar, namun tidak ada hubungannnya dengan kelebihan nutrisi (obesitas). ${ }^{16}$

Lingkar otot lengan atas (LOLA) didapatkan dengan pengukuran lipatan triseps dan lingkar lengan atas (LLA). Pengukuran lipatan triseps dimaksudkan untuk menentukan status lemak tubuh sementara pengukuran LLA dan LOLA untuk mengetahui status protein otot. Kurang lebih separuh jaringan adiposa tubuh terdapat dalam jaringan subkutan sehingga pengukuran status lemak tubuh dapat dilakukan pada lipatan triseps, subskapula, abdominal, panggul serta paha. Namun untuk kemudahan pengukuran ini biasanya dilakukan pada bagian triseps dan biasanya jarang ada edema di daerah ini. Sejumlah penelitian menunjukkan bahwa penilaian lemak subkutan lewat pengukuran lipatan kulit merupakan cara yang cukup akurat. Ukuran LLA menentukan massa otot dan jaringan subkutan. ${ }^{16,17}$

Metabolisme lemak pada kakhesia kanker terjadi penurunan lemak paling besar yaitu sekitar $85 \%$ baik melalui peningkatan lipolisis atau penurunan lipogenesis. Perubahan metabolisme lemak yang sering ditemukan pada penderita keganasan adalah hiperlipidemia, berkurangnya cadangan lemak tubuh dan penurunan enzim lipoprotein lipase (LPL) yang berfungsi sebagai clearance. Keadaan ini dapat menekan sistim imun tubuh, khususnya menghambat efek dari monosit dan makrofag. Pasien kanker sering 
mengalami perubahan gliserol dan asam lemak yang tinggi, serta peningkatan mobilisasi lipid yang terjadi bahkan sebelum terjadi penurunan berat badan. Beberapa penelitian mengamati peningkatan mobilisasi asam lemak sebelum terjadi penurunan berat badan diduga karena lipid mobilizing factor (LMF). Mobilisasi asam lemak dari jaringan adiposa merupakan faktor penting yang berperan untuk pertumbuhan tumor. Pada penelitian ditemukan adanya peningkatan dua kali lipat pada jumlah messenger ribonucleid acid (mRNA) untuk hormon sensitive lipase yang diperlukan pada cyclic AMP- dependent pada rangkaian lipolitik. Peran dari sitokin TNF- $\alpha$, IL6 , IL- $1 \alpha$, IFN- $\gamma$ adalah menghambat enzim LPL, sehingga lipogenesis juga terhambat. Beberapa penelitian juga menemukan bahwa TNF- $\alpha$ dapat secara langsung menstimulasi lipolisis dengan cara mengaktivasi mitogen-activated protein kinase (MEK) dan extracellular signal-related kinase (ERK) serta dengan meningkatkan AMP siklik intraselular. LMF yang ditemukan pada urin penderita kakheksia kanker, secara langsung menstimulasi lipolisis melalui interaksi dengan adenilat siklase pada proses dependent guanosine triphosphate (GTP). ${ }^{18,19}$

Metabolisme protein pada pasien kanker yaitu terjadi peningkatan perubahan protein, peningkatan sintesis protein di hati, penurunan sintesis protein di otot rangka dan pemecahan protein otot yang berakibat wasting. Berkurangnya massa otot rangka merupakan perubahan yang paling penting pada kakheksia kanker. Massa otot dapat berkurang sekitar $75 \%$ ketika terjadi kehilangan berat badan sebesar 30\% dan keadaan tersebut sangat berbahaya. Degradasi protein pada otot akan melepaskan beberapa asam amino, khususnya alanin dan glutamin. Glutamin merupakan asam amino yang paling besar jumlahnya dan mempunyai beberapa fungsi, Salah satunya adalah dipergunakan sel untuk membelah diri. Sel tumor banyak menggunakan glutamin dan berkompetisi dengan sel normal. ${ }^{18-22}$

Kadar albumin dalam serum merupakan parameter yang dapat digunakan untuk menilai status nutrisi. Penurunan kadar albumin dalam serum merupakan salah satu alat yang digunakan untuk menilai protein tubuh. Penilaian protein tubuh, konsentrasi protein dalam serum seperti retinol-binding protein, transferin, prealbumin, dan albumin dapat digunakan untuk menilai derajat hilangnya protein tubuh. Metabolisme protein pada pasien kanker yaitu terjadi peningkatan turn-over protein, peningkatan sintesis protein di hati, penurunan sintesis protein di otot rangka dan pemecahan protein otot yang berakibat wasting. Perubahan peningkatan sintesis protein di hepar menurunkan kadar albumin, yang dihasilkan acute phase response (APR) seperti c-reactive protein (CRP), protein serum amyloid $A, \beta_{2}-$ macroglobulin dan

$\alpha_{-1}$ antitrypsin. Munculnya APR ini dihubungkan dengan terjadinya kehilangan berat badan pada pasien dengan kanker paru, pankreas, dan melanoma. Kehadiran APR ini dihubungkan juga dengan singkatnya survival time pada pasien kanker ginjal, pankreas dan kolon. Kadar albumin dalam serum memiliki keterbatasan sebagai parameter status nutrisi karena memiliki waktu paruh yang panjang. Albumin disintesis di hepar dan memiliki waktu paruh rata-rata 20 hari. ${ }^{16,19,20}$

Kadar transferin juga dapat digunakan sebagai salah satu parameter yang sering digunakan untuk menilai status nutrisi. Perubahan peningkatan dari sintesis protein di hepar menjadi albumin menghasilkan acute phase response (APR) seperti c-reactive protein (CRP), protein serum amyloid $A, \beta_{2}$ macroglobulin dan

$\alpha_{-1}$ antitrypsin. APR diaktivasi dan diatur oleh produk-produk sitokin, yang paling jelas ditemukan hubungan antara APR dengan jumlah serum IL-6 dan TNF reseptor 55 dan 75. Selanjutnya faktor tumor yang dihubungkan dengan kakheksia seperti proteolysis-inducing factor (PIF), yang mengaktifkan faktor transkripsi Nuclear Factor-kappa B (NF-kB) akan meningkatkan produksi sitokin IL-8, IL-6, CRP dan menurunkan produksi transferin. Transferin merupakan protein plasma yang berfungsi mengikat dan sebagai transport besi $(\mathrm{Fe})$ dalam 
darah. Transferin disintesis di hepar dan memiliki waktu paruh 8-10 hari. Hal ini menjadikan transferin menjadi lebih sensitif daripada albumin untuk menilai perubahan status nutrisi. Transferin tidak dapat digunakan untuk menilai status nutrisi pada keadaan kekurangan atau kelebihan Fe dan pada penderita yang menerima beberapa jenis transfusi. Jadi pada pasien dengan anemia dan sesudahnya ditransfusi tidak diikutsertakan dalam penelitian ini. ${ }^{16,20}$

Munculnya gejala mukositis mulai dinilai pada pertengahan radioterapi yaitu hari ke 20 . Pada penderita kanker kepala dan leher yang menjalani radioterapi gejala mukositis ini muncul biasanya pada akhir minggu pertama sesudah terapi radiasi. Tanda dan gejala awal mukositis oral adalah eritema, edema, rasa terbakar dan meningkatnya sensitivitas terhadap makanan yang panas dan pedas. Eritema biasanya muncul pada minggu pertama radiasi sedangkan bercak pseudomembran atau gabungan pseudomembran terlihat jelas pada minggu ke-empat dan ke-lima radiasi. Selain itu faktor radiasi yang dapat meningkatkan risiko mukositis adalah dosis, fraksionasi, dosis keseluruhan dan luas mukosa yang mendapat radiasi, Peningkatan fraksi radiasi akan meningkatan risiko mukositis sampai lebih dari $70 \%$. Berdasarkan patogenesis dari mukositis karena radioterapi terdiri dari 5 fase. Fase pertama adalah fase inisiasi dimana terjadi kerusakan DNA dan non-DNA yang dapat terlihat pada mukosa dan submukosa. Pada fase ini sebagai awal pencetus munculnya stres oksidatif dan terbentuknya radikal bebas yang berakibat terjadinya kerusakan sel-sel mukosa, jaringan dan pembuluh darah. Fase kedua adalah fase message generation terjadi "upregulation of transcription factors" seperti NF kB dan pengkodean gen proinflamasi seperti TNF- $\alpha$ dan interleukin (IL-1, IL-2, IL-6) serta molekul-molekul adhesi. Terjadi aktivasi enzim-enzim seperti spingomielinase dan sintesis ceramide yang menyebabkan apoptosis sel-sel endotel submukosa dan fibroblast. Penghancuran fibroblast akan menghasilkan fibronektin yang akan merusak jaringan ikat dan melepaskan metalloproteinase yang menyebabkan apoptosis. Secara makro belum menyebabkan perubahan mukosa. Fase ketiga adalah fase signaling dan amplification, terjadi pelepasan mediator inflamasi dari daerah yang mendapat radiasi yang akan memicu proses perusakan sel yang berjalan terus-menerus sehingga proses penyembuhan menjadi terhambat. Fase keempat yaitu fase ulserasi, terjadi kerusakan pada rongga mulut berupa daerah erosi yang ditutupi oleh eksudat fibrin yang disebut pseudomembran. Biasanya berisi bakteri Gram negative. Kolonisasi di mukosa dapat mengaktivasi makrofag yang memberikan umpan balik positif dan menambah sekresi sitokin proinflamasi yaitu PAF (Platelet Activating Factor). Fase kelima adalah fase penyembuhan, terjadi penutupan, proliferasi dan differensiasi sel epitel pada daerah luka. Sel-sel di bawah pseudomembran berusaha menutup dan sel lekosit darah kembali normal. Proliferasi sel terjadi sampai mukosa mencapai ketebalan yang normal. ${ }^{23-25}$

Hubungan BMI, LOLA, albumin dan transferin sebelum radioterapi dipengaruhi oleh berbagai faktor antara lain penderita dengan usia diatas 50 tahun risikonya bertambah besar karena kemampuan DNA untuk memperbaiki diri rendah. Penderita dengan jenis kelamin wanita, status nutrisi, jenis kanker, status periodontal, masalah higiene rongga mulut dan kebiasaan merokok yang sudah ada sebelum radiasi merupakan faktor penderita yang dapat menimbulkan atau memperberat kondisi mukositis. Malnutrisi dapat meningkatkan risiko keparahan mukositis karena malnutrisi protein kalori dapat menyebabkan dehidrasi yang dapat mengiritasi mukosa dan meningkatkan kerusakan gigi serta penyembuhan mukosa oral yang lambat. Menurut penelitian yang dilakukan Rugg et $\mathrm{al}^{27}$ pola kebiasaan merokok penderita kanker yang dilakukan radiasi mempunyai korelasi nyata dengan lamanya mukositis yang diamati dari hari pertama radioterapi. Dari penelitian ini diketahui bahwa tidak adanya hubungan yang signifikan antara status nutrisi (BMI, LOLA, albumin, transferin) 
sebelum radioterapi dengan kejadian mukositis oleh karena dipengaruhi banyak faktor tersebut diatas. $^{23,26,27}$

Hubungan kejadian mukositis dengan BMI, LOLA, albumin dan transferin sesudah radioterapi dipengaruhi antara lain oleh 3 faktor yaitu, faktor tumor, faktor pasien dan faktor terapi. Faktor tumor antara lain, penurunan berat badan yang berat didapatkan pada tumor yang ada di orofaring atau rongga mulut, nasofaring, dan hipofaring. Selain itu juga terjadi metabolisme karbohidrat, protein, dan lemak secara tidak normal. Produk dari tumor yang mempunyai efek katabolik langsung pada jaringan host yaitu LMF, yang bereaksi pada jaringan adiposa dan PIF yang bereaksi pada otot rangka. Faktor dari pasien dipengaruhi oleh produk dari jaringan host, seperti tumor necrosis factor- $\alpha$ ( TNF- $\alpha$ ), interleukin-1 (IL-1) dan IL-6, interferon- $\gamma$ (IFN- $\gamma$ ), dan leukemia inhibitory factor (LIF) yang turut berperan dalam metabolisme karbohidrat, protein, dan lemak secara tidak normal. Faktor pasien yang lain anoreksia pada keganasan akan meningkatkan metabolisme nutrisi tubuh, terbuangnya 100 kalori non-protein dalam sehari berperan pada hilangnya berat badan dan masa tubuh dalam jangka panjang. Riwayat kebiasaan buruk pasien seperti merokok, minum alkohol dan konsumsi tembakau merupakan faktor risiko yang utama untuk pasien kanker dan penggunaan yang terus-menerus dihubungkan dengan meningkatnya oxidative stress dan menurunnya serum antioksidan pada tingkat mikronutrisi. ${ }^{6,13,19,20,28}$

Faktor terapi anti kanker yaitu pada radioterapi: letak titik sasaran radiasi, besaran radiasi, dan durasi radiasi akan mempengaruhi keadaan nutrisi penderita keganasan. Pemberian radiasi merupakan pengalihan energi dari radiasi pengion ke dalam sel-sel. Terjadi deposit fisik dari energi yang akan diikuti oleh berbagai peristiwa yang menimbulkan dampak pada sel. Berbagai cedera yang mungkin terjadi akibat interaksi sinar pengion pada DNA antara lain 40 double stranbrake (DSB), 500-1000 single strandbrake (SSB) per Gy per sel diploid. Cedera lain berupa cedera pada rantai basa DNA, pada rantai glukosa, crosslinks DNA-DNA dan DNA protein. Pengaruh terhadap nutrisi ini bisa terjadi karena efek samping radioterapi akut maupun lambat. Reaksi akut dapat terjadi dalam 3 hari sampai 1 minggu terapi, berupa kesulitan menelan akibat edema dan mukositis orofaring menyebabkan disfagia dan odinofagia, penurunan produksi saliva serta hilangnya sensasi pengecapan. Efek samping lanjut berupa peradangan mukosa persisten, fibrosis intestinal dan striktur. Pada sebuah penelitian disebutkan bahwa penurunan berat badan pada penderita keganasan kepala - leher sesudah 6-8 minggu terapi radiasi ratarata $3,7 \mathrm{~kg}$ pada $93 \%$ dari 114 penderita. Selain itu, hampir 9\% penderita mengalami penurunan berat badan lebih dari $1 / 10$ berat badan idealnya sesudah menjalani terapi radiasi 6-8 minggu. ${ }^{20}$ Selain mukositis dapat juga dipengaruhi oleh efek samping dari radioterapi yang lain seperti serostomia dan gangguan pengecapan. Serostomia merupakan efek samping radioterapi karena kelenjar parotis juga terkena dosis radiasi sebanyak radiasi eksterna yang diterima oleh nasofaring. Serostomia dapat menyebabkan menurunnya produksi air liur, mengurangi kualitas sistim fisiologis air liur, meningkatkan viskositas, meningkatkan keasaman air liur, dan menurunnya IgA oral sehingga menyebabkan tingginya perkembangan karies dan infeksi flora mulut. Selama masa radioterapi kuratif konvensional dengan dosis 6000-7000 cGy selama 6-8 minggu, fungsi pengecapan mulai mengalami kerusakan pada minggu pertama terapi, yang diawali dengan rasa pahit dan gangguan makin bertambah selama minggu kedua pengobatan. Kerusakan fungsi pengecapan mencapai puncaknya pada minggu ketiga, keempat dan sampai siklus terakhir dari keseluruhan radiasi. Berdasarkan pada ambang pengecapan, rasa pahit dan asin menunjukkan kerusakan lebih awal dan lebih parah dibandingkan dengan rasa manis yang mengalami gangguan terakhir. ${ }^{11,14,15,20,23}$

Penderita dengan usia di atas 50 tahun risikonya bertambah besar karena kemampuan 
DNA untuk memperbaiki diri rendah. Pada penelitian Rugg et al ${ }^{27}$ dari 41 penderita kanker kepala leher yang diteliti berusia antara 18-83 tahun, hasil penelitian tersebut tidak terdapat korelasi antara usia dan jenis kelamin dengan kejadian dan lamanya mukositis yang diamati dari minggu pertama radiasi. Sebuah literatur menyebutkan bahwa wanita mempunyai risiko lebih besar terjadinya mukositis oral yang parah dibanding pria, pada penderita yang menjalani kemoterapi dengan fluorouracil dan methotrexate. Literatur lain menyatakan bahwa jenis kelamin bukanlah faktor risiko karena tidak ada perbedaan antara pria dan wanita terhadap terjadinya mukositis oral yang parah. ${ }^{26,29}$ Dari literatur tidak ada yang menyebutkan tentang mukositis yang dipengaruhi oleh stadium tapi hanya disebutkan jenis kanker pada penderita dan luasnya mukosa yang diradiasi. Pada kanker kepala dan leher insiden mukositis mencapai $85-100 \%$ dan kurang lebih $25-45 \%$ mengalami mukositis derajat 3 dan $4 .{ }^{25}$ Sedangkan pada penelitian yang dilakukan Rugg et al, ${ }^{27}$ terdapat korelasi yang signifikan antara radiasi pada mukosa dengan volume kecil dengan lamanya durasi mukositis. Semakin kecil jumlah volume mukosa yang dilakukan radiasi maka semakin cepat waktu yang dibutuhkan dari mulai terjadinya mukositis sampai penyembuhan, diamati dari hari pertama radioterapi. . $^{24,25-27,29}$

Dari penelitian disimpulkan bahwa pemberian radioterapi pada penderita KNF WHO tipe III stadium lanjut menyebabkan penurunan status nutrisi, yang dinilai dari parameter BMI, LOLA dan transferrin. Untuk status nutrisi penderita KNF WHO tipe III stadium lanjut sebelum radioterapi ternyata tidak terdapat hubungan secara bermakna dengan kejadian mukositis sesudah radioterapi, status nutrisi penderita KNF WHO tipe III stadium lanjut sesudah radioterapi tidak berhubungan secara bermakna dengan kejadian mukositis sesudah radioterapi dan usia, jenis kelamin dan stadium penderita KNF WHO tipe III stadium lanjut tidak berhubungan secara bermakna dengan kejadian mukositis sesudah radioterapi.

\section{DAFTAR PUSTAKA}

1. Mould RF, Tai THP. Nasopharyngeal carcinoma treatments and outcome in the $20^{\text {th }}$ century. British $\mathrm{J}$. Radiol. 2002; 75:307-39.

2. Paulino AC. Nasopharyngeal cancer [cited 2010 December 14]. Available from: http://emedicine. medscape.com/article/988165-overview.

3. Mulyarjo. Diagnosis dan penatalaksanaan karsinoma nasofaring. Dalam: Naskah Lengkap Pendidikan Kedokteran Berkelanjutan III Ilmu Kesehatan THTKL. Surabaya, 2002.

4. Brickman TM, Doerr T, Jeyakumar A. Review of nasopharyngeal carcinoma. J. Ear, Nose and Throat 2006; 85(3): 168-73.

5. Roezin A, Adham M. Karsinoma nasofaring. Dalam: Soepardi EA, Iskandar N, Bashirudin J, Restuti, editors. Buku Ajar Ilmu Kesehatan THT. Jakarta: Balai Penerbit FK UI, 2007. h.182-7.

6. Argiles JM, Olivan M, Busquets S, Lopez S. Optimal management of cancer anorexia-cachexia syndrome. J Cancer Man Res. 2010; 2:27-38.

7. Wittenar JH, Dijkstra PU, Vissink A, Van Oort RP, Rodenberg J. Critical weight loss in head and neck cancer-prevalance and risk factors at diagnosis: an explorative study. J. Support Care Cancer. 2007; 15:1045- 50 .

8. Lin HS. Malignant nasopharyngeal tumors [cited 2010 October 8]. Available from: http://emedicine. medscape.com/article/848163-overview.

9. Redding SW. Cancer therapy related oral mucositis. J. Dent Educ. 2005; 69(8):919-29.

10. Muscaritoli M, Molfino A, Gioia G, Laviano A, Fanello FR. The "parallel pathway": a novel nutrition and metabolic approach to cancer patients. J. Intern Emerg Med 2011; 6(2):105-12.

11. Maskoep WI. Terapi nutrisi pada penderita kanker. Pusat pengembangan paliatif dan bebas nyeri. Surabaya: Dr. Soetomo-FK UNAIR, 2007.

12. Mangar S, Slevin N, Mais K, Sykes A. Evaluating predictive factors for determining enteral nutrition in patient receiving radical radiotherapy and oncology: a retrospective review. J. Radiother Oncol. 2006; 78:152-8.

13. Sutandyo N. Nutrition problem in cancer patient. Workshop nutrition support for cancer patients. Batu, Malang, 2010

14. Susworo R. Kanker Nasofaring. Dalam: Radioterapi. Jakarta: UI Press; 2007. p.64-77.

15. Redda MGR, Allis S. Complication of treatment radiotherapy - induced taste impairment. Cancer Treatment Rev. 2006; 32:541-7. 
16. Hartono A. Kanker. Dalam: Ester M editor. Terapi gizi dan diet rumah sakit. $2^{\text {nd }}$ ed. Jakarta: EGC; 2004. h.167-72.

17. Russell RM, Jacob RA, Greenberg LB. Penilaian klinis status nutrisi orang dewasa. Dalam: Linder MC, editor. Biokimia nutrisi dan metabolisme. Jakarta: UI Press; 2006. h. 509-24.

18. Sutandyo N. Terapi nutrisi pada pasien kanker. Dalam: Sudoyo AW, Setyohadi B, Alwi I, editors. Buku ajar IPD. Jakarta: Pusat Penerbitan Departemen IPDFKUI; 2006. h.342 -6.

19. Tisdale MJ. Pathogenesis of cancer cachexia. J. Support Oncol. 2003; 1:159-68.

20. Koutkia P, Apovian C, Blackburn G. Nutrition support. In: Berger A, Partenoy RK, Weissman DE, editors. Principles and practice of palliative care and supportive oncology. $2^{\text {nd }}$ ed. Philadelphia: Lipincott Williams and Wilkins; 2002. p.1430-63.

21. Smith JS, Souba WW. Nutrition suport In: Derita VT, Hellman S, Rosenberg SA, editors. Cancer: principles and practice of oncology. Philadelphia: Lipincott Williams and Willkins; 2001. p. 602 -53.

22. Tisdale MJ. Biology of cachexia. J. Natl Cancer Inst
1997; 89(23): 1763-73.

23. Wolfgang J, Kostler, Hejna M, Wenzel C, Christoph C, Zielinski. Oral mucositis complicating chemotherapy and/or radiotherapy: options for prevention and treatment. Cancer J Clin. 2001; 51:290-315.

24. Lionel D, Christope L, Marc A, Jean- Luc C. Oral mucositis induced by anticancer treatment: physiopathology and treatments. J Ther Clin Risk Manag 2006 June; 2(2):159-68.

25. Silverman S. Diagnosis and management of oral mucositis. J. Support Oncol. 2007; 5(2 Suppl 1):13-21.

26. Sufiawati I. Identifikasi dan pengendalian faktor risiko mukositis oral selama radioterapi kanker nasofaring. Tesis. Bandung Fakultas Kedokteran Gigi, Universitas Padjajaran, 2006.

27. Rugg T, Saunders M, Dische S. Smoking and mucosal reactions to radiotherapy. The $\mathrm{Br} J$ Radiol. 1990; 63:554-6.

28. Kucuk O, Ottery FD. Dietary supplements during cancer treatment. J. Oncol. 2002; 17(2):22-6.

29. Kintzel P. Management of oral mucositis in cancer patients. [cited 2010 February 18]. Available from: http.issuu.com/mcmahongroup/docs/conhem1011_de. 